\title{
PERILAKU STRUKTUR GEDUNG BERTINGKAT KETIDAK BERATURAN VERTIKAL KEKAKUAN TINGKAT LUNAK DENGAN ANALISIS BERBASIS KINERJA
}

\author{
Arbain Tata \\ Program Studi Teknik Sipil, Fakultas Teknik, Universitas Khairun \\ Jln. Pertamina Gambesi Ternate 55281 Indonesia \\ email:arbain.tata@unkhair.ac.id
}

DOI: http://dx.doi.org/10.29103/tj.v11i2.475

(Received: January 2021 / Revised: March 2021 / Accepted: May 2021)

\begin{abstract}
Abstrak
Perkembangan disain struktur bangunan tahan gempa menggunakan konsep Performance Based Design atau analisis berbasis kinerja adalah konsep desain struktur bangunan gedung di mana kegagalan dapat didesain terjadi pada level dan pola tertentu sesuai tingkat kerusakan yang diinginkan. Dalam penerapan konsep Performance Based Design digunakan metode perhitungan perpindahan langsung atau Direct Displacement Based Design (DDBD). Pada penelitian ini struktur gedung merupakan konstruksi beton bertulang dengan pola denah yang beraturan di mana keseluruhan tipe struktur A0, B1, B2, dan B3 yang didesain menggunakan sistem ganda pada arah sumbu kuat (x) dan sistem rangka pada arah sumbu lemah (y). Struktur A0 merupakan struktur dasar yang menjadi pembanding terhadap ketidak beraturan vertikal kekakuan tingkat lunak yang didesain pada Struktur B1, B2, dan B3. Evaluasi hasil kinerja dan asesmen menggunakan metode ATC-40 diketahui bahwa, untuk keseluruhan tipe struktur A0, B1, B2, dan B3 pada arah x dan y berada pada level kinerja Immediate Occupancy (IO) dan termasuk dalam kategori daktilitas penuh (full ductility). Hasil perbandingan nilai drift pada arah sumbu (x) pada sistem ganda diketahui bahwa semua tipe struktur nilainya tidak melebihi design drift limit, sedangkan hasil perbandingan nilai drift pada arah sumbu (y) pada sistem rangka diketahui bahwa struktur B1 dan B2 memiliki nilai drift yang melebihi design drift limit.
\end{abstract}

Kata kunci: perilaku, ketidakberaturan vertikal, analisis berbasis kinerja

\begin{abstract}
The development of earthquake-resistant building structural designs using the concept of Performance-based design or performance-based analysis is the design concept of building structures where failure can be designed to occur at a certain level and pattern according to the level of damage. The implementation of the concept of Performancebased design use the method of calculating direct displacement or Direct Displacement Based Design (DDBD). Therefore, the building structure is a reinforced concrete construction with a regular floor plan where all types of structures A0, B1, $\mathrm{B} 2$, and $\mathrm{B} 3$ are designed using a dual system on the strong axis (x) and the frame system on the weak axis (y). The structure A0 is the basic structure which is a comparison to the vertical irregularity of soft stiffness designed in Structures B1, B2, and B3. Evaluation of performance results and assessment using the ATC-40 method indicate for all types of structures A0, B1, B2, and B3 in the $\mathrm{X}$ and $\mathrm{Y}$ directions are at the level of performance of Immediate Occupancy (IO) and are included in the full
\end{abstract}

Perilaku Struktur Gedung Bertingkat Ketidakberaturan Vertikal Kekakuan Tingkat 
ductility category. The results of the comparison of drift values in the (x) direction of the dual system show that all types of structures do not exceed the design drift limit. Meanwhile, the results of the comparison of drift values in the (y) direction of the frame system show that the structures B1 and B2 have drift values that exceed the design drift limit.

Keywords: behavior, vertical irregularity, performance-based analysis

\section{Latar Belakang}

Indonesia merupakan suatu negara yang perkembangan penduduknya begitu pesat, sehingga dengan perkembangan penduduk yang begitu pesat akan membutuhkan ruang tinggal serta fasilitas penunjang hidup dan aktifitas kegiatan perekonomian yang terpadu (Resti Oktaviani, 2016). Sejalan dengan perkembangan ekonomi dan tuntutan mengenai bangunan gedung yang bisa memenuhi kebutuhan masyarakat di perkotaan, melahirkan ide yang mana bahwa bangunan gedung tidak hanya berfungsi sebagai tempat tinggal ataupun perkantoran saja, suatu bangunan gedung dengan fungsi yang beragam lebih tepat untuk mengakomodir berbagai kegiatan khususnya di perkotaan. Gedung dengan fungsi yang beragam dapat mengakibatkan ketidakberaturan struktur vertikal dan horisontal yang mana ketidakberaturan struktur yang sering terjadi akibat dari pemenuhan kebutuhan ruang bangunan gedung yaitu ketidak beraturan vertikal kekakuan tingkat lunak. Ketidakberaturan kekakuan tingkat lunak didefinisikan ada jika terdapat suatu tingkat di mana kekakuan lateralnya kurang dari $70 \%$ kekakuan lateral tingkat di atasnya atau kurang $80 \%$ kekakuan rata-rata 3 tingkat di atasnya (ACI-318, 2014).

Pada dasarnya, metode desain struktur beton terbagi menjadi dua, yaitu metode tegangan kerja (working stress method) yang berbasis teori elastis dan metode kekuatan ultimit (ultimate strength method) (A, Imran and Imron, 2018), namun seiring perkembangan ilmu pengetahuan di dunia konstruksi dan bahan material maka yang terbaru saat ini adalah konsep desain gempa berbasis kinerja (performance based design) di mana daktailitas, kapasitas deformasi dan kapasitas beban pada deformasi yang besar menjadi parameternya (Cimellaro, Giovine and Lopez-Garcia, 2014).

Selain itu, Indonesia sendiri merupakan negara yang berada di wilayah jalur gempa pasifik (Circum Pasific Earthquake Belt) dan jalur gempa asia (Trans Asiatic Earthquake Belt) sehingga sangat berpotensi untuk mengalami gempa, karena itu Indonesia termasuk dalam jalur cincin api Pasifik (Ring of Fire) (Hakim, Alama and Ashour, 2014). Cincin api Pasifik merupakan rangkaian gunung aktif di dunia yang menyebabkan Indonesia mengalami frekuensi gempa yang cukup sering, hal ini menegaskan pentingnya tinjauan beban gempa rencana dalam perencanaan desain struktur sebagai antisipasi apabila terjadi gempa (Hamidia, Filiatrault and Aref, 2015).

Analisis non linier pushover (ATC 40, 1997) merupakan salah satu komponen performance based design yang menjadi sarana dalam mencari kapasitas dari suatu struktur. Dasar dari analisis pushover sebenarnya sangat sederhana yaitu memberikan pola beban tertentu dalam arah lateral yang ditingkatkan secara bertahap pada suatu struktur sampai struktur tersebut mencapai target displacement tertentu atau mencapai pola keruntuhan tertentu. 
Dari hasil analisis tersebut dapat diketahui nilai gaya geser dasar untuk perpindahan lantai atap tertentu (Hakim, Alama and Ashour, 2014; Saleemuddin and Sangle, 2017; Tafakori, Pourzeynali and Estekanchi, 2017; Narayan et al., 2018; Mirjalili and Rofooei, 2020).

Penelitian ini dilakukan dengan menggunakan pola denah yang beraturan di mana keseluruhan tipe struktur A0, B1,B2, dan B3 yang didesain menggunakan sistem ganda pada arah $\mathrm{x}-\mathrm{x}$ dan sistem rangka pada arah $\mathrm{y}-\mathrm{y}$. Struktur A0 merupakan struktur dasar yang menjadi pembanding terhadap ketidakberaturan vertikal kekakuan tingkat lunak yang didesain pada Struktur B1, B2, dan B3. Ketidakberaturan vertikal kekakuan tingkat lunak didefinisikan ada pada struktur B1, B2, dan B3 jika terdapat suatu tingkat yang kekakuan lateralnya kurang dari $70 \%$ kekakuan lateral tingkat di atasnya atau kurang dari $80 \%$ kekakuan rata rata tiga tingkat diatasnya dengan lokasi di gempa di wilayah (Lilik Hendri Suryo Anom, Wibowo Wibowo, 2013).

Penelitian ini dilakukan untuk mengetahui perilaku struktur dengan ketidakberaturan vertikal kekakuan tingkat lunak untuk menunjukkan kurva kapasitas, hubungan base shear dengan displacement pada kurva pushover sebagai tahapan perilaku struktur saat terjadi gaya geser dasar pada level tertentu serta performance point (Kalkan and Kunnath, 2006; Filiatrault and Sullivan, 2014; Hakim, Alama and Ashour, 2014; Pangemanan and Mantiri, 2017; A, Imran and Imron, 2018; Fajfar, 2018; Saedi-Daryan, Soleimani and Hasanzadeh, 2018).

\section{Metode Penelitian}

Pada penelitian ini dilakukan dengan pemodelan pada 2 jenis struktur bangunan yaitu struktur bangunan dasar A0 (beraturan) dan struktur bangunan dengan ketidak beraturan lateral tingkat lunak B1, B2, dan B3. Struktur bangunan dasar A0 akan menjadi pembanding terhadap struktur bangunan dengan ketidakberaturan lateral tingkat lunak bangunan yang lain seperti pada Gambar 3, dengan pendekatan kuantitatif yang merupakan hasil analisis struktur gedung dengan menggunakan Finite Element.
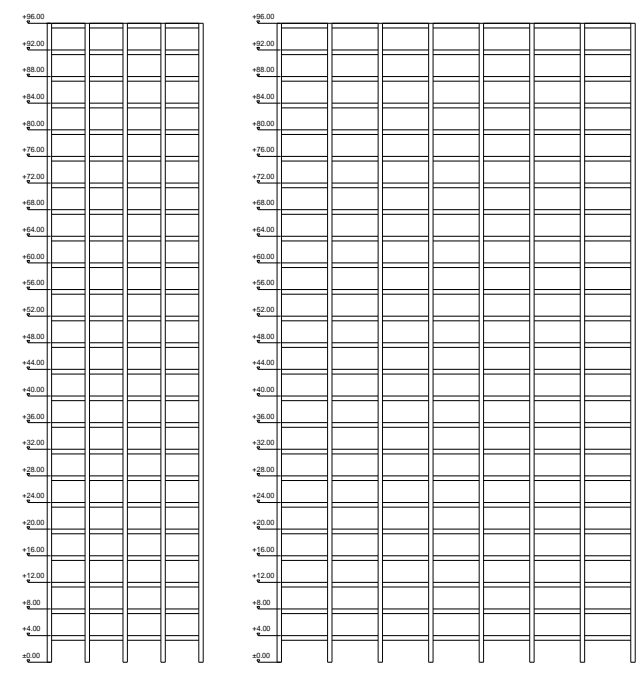

a. Model struktur gedung A0
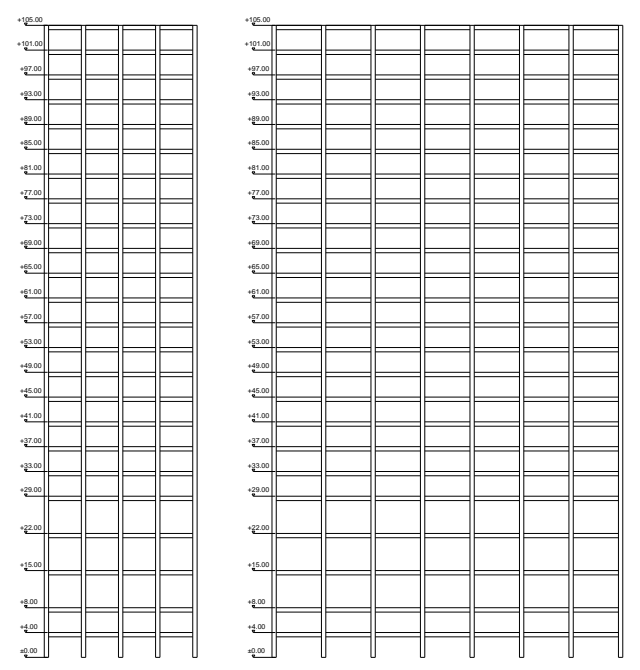

b. Model struktur gedung B1 

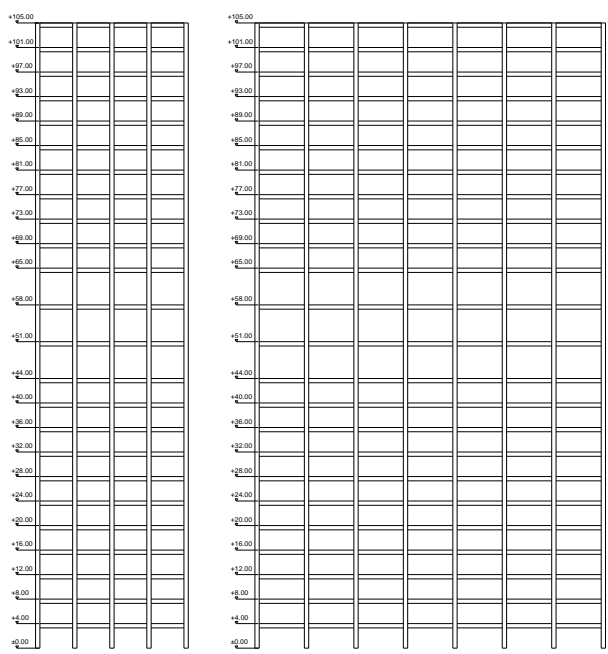

c. Model struktur gedung B2
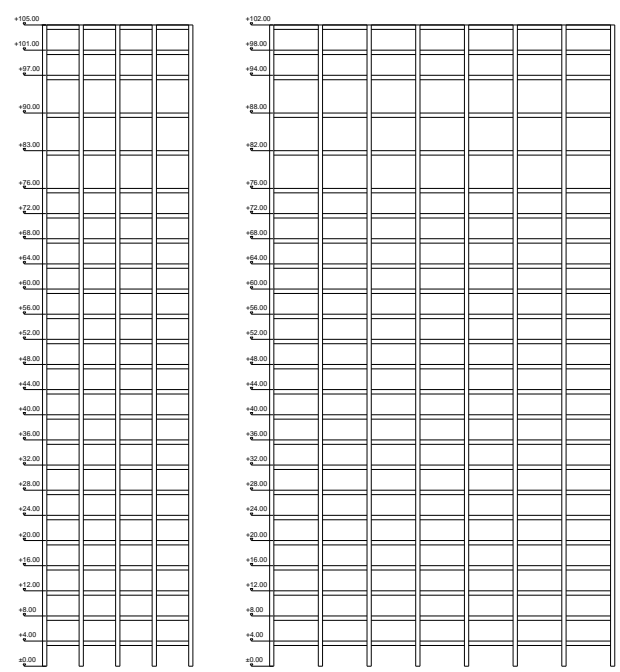

d. Model struktur gedung B3

Gambar 1 Model struktur gedung A0, B1, B2, dan B3

Analisis pembebanan dengan beban mati, hidup dan gempa wilayah Ternate. Adapun sumber data yang digunakan adalah: fungsi bangunan berupa perkantoran, tinggi bangunan masing-masing Struktur A0 adalah 96 m, Struktur B1, B2, dan B3 sebesar $105 \mathrm{~m}$. Tinggi lantai tipikal adalah $4 \mathrm{~m}$, tinggi lantai kekakuan tingkat lunak adalah $7 \mathrm{~m}$. Sistem struktur merupakan Sistem Ganda arah sumbu (x) dan SRMK arah sumbu y. Mutu beton (fc') $35 \mathrm{MPa}$, Mutu baja (fy) $420 \mathrm{MPa}$ (Kalkan and Kunnath, 2006; Budiono, 2016; Zeng et al., 2016; Sulthan, 2017; Vafaei and Alih, 2018).

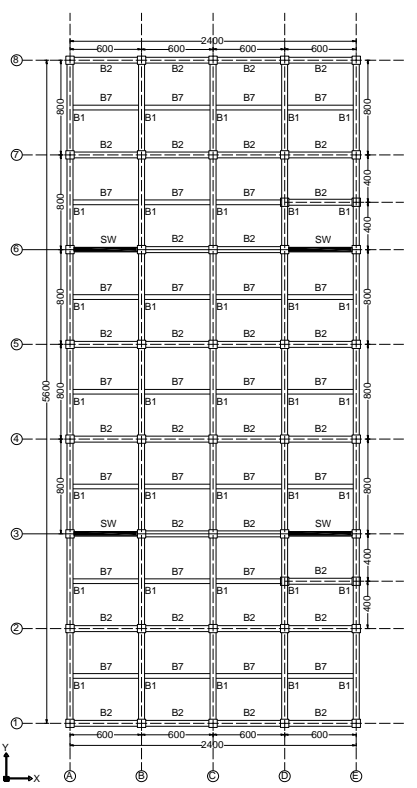

a. Denah lantai 1-8

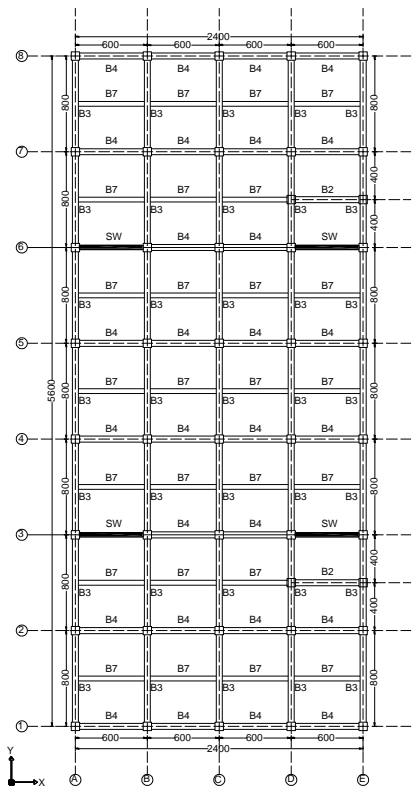

b. Denah lantai 9-16

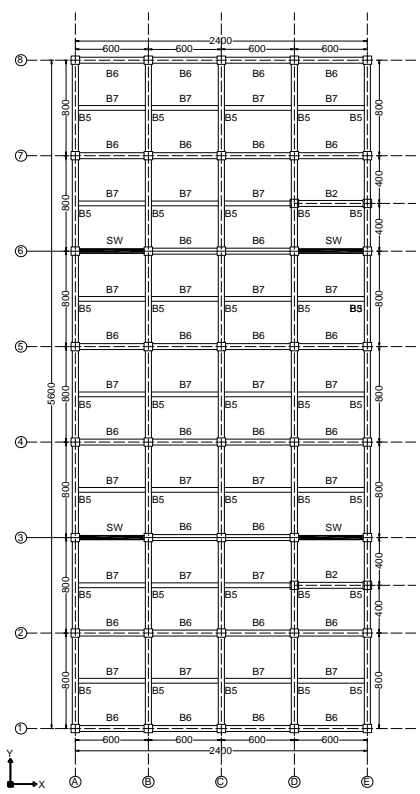

c. Denah lantai $17-24$

Gambar 2 Denah struktur bangunan dasar A0, B1, B2, dan B3 
Tabel 1 Tebal pelat dan dimensi

\begin{tabular}{ccc}
\hline Tipe & Struktur A0, B1, B2, dan B3 $(\mathrm{cm})$ & Lokasi \\
\hline Balok B1 & $50 \times 80$ & Lt 1-8 \\
\hline Balok B2 & $40 \times 60$ & Lt 1-8 \\
\hline Balok B3 & $50 \times 70$ & Lt 9-16 \\
\hline Balok B4 & $40 \times 60$ & Lt 9-16 \\
\hline Balok B5 & $40 \times 60$ & Lt 17-24 \\
\hline Balok B6 & $35 \times 50$ & Lt 17-24 \\
\hline Balok B7 & $35 \times 50$ & Lt 1-24 \\
\hline Kolom K1 & $120 \times 120$ & Lt 1-8 \\
\hline Kolom K2 & $90 \times 90$ & Lt 9-16 \\
\hline Kolom K3 & $60 \times 60$ & Lt 17-24 \\
\hline Dinding Geser & 35 & Lt 1-24 \\
\hline Pelat Lantai & 14 & Lt 1-24
\end{tabular}

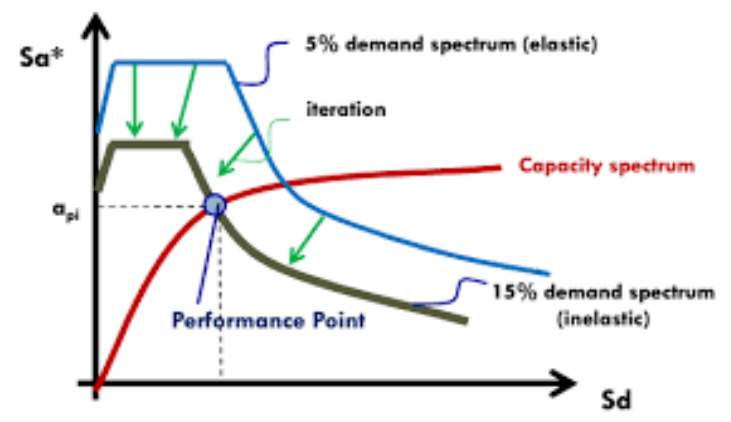

Gambar 3 Hubungan capacity curve dan demand (ATC-40)

Dasar dari prosedur Direct Displacement Based Design (DDBD) adalah struktur tidak didesain lagi dengan karakteristik elastik awal, akan tetapi struktur akan didesain dengan karakteristik inelastik struktur pada tingkat kinerja desain (Pangemanan and Mantiri, 2017). Prosedur desain DDBD untuk sistem rangka:

1. Desain perpindahan untuk sistem rangka ditentukan berdasarkan inelastik mode shape dan tinggi masing-masing lantai. Perhitungan nilai inelastik mode shape dihitung berdasarkan jumlah lantai rencana

$$
\begin{array}{ll}
\text { Untuk } n \leq 4, & \delta_{i}=\frac{H_{i}}{H_{n}} \\
\text { Untuk } n>4, & \delta_{i}=\frac{4}{3}\left(\frac{H_{i}}{H_{n}}\right)\left(1-\frac{H_{i}}{4 H_{n}}\right)
\end{array}
$$

2. Desain perpindahan tingkat MDOF harus dikonversi kedalam sistem SDOF, di mana perpindahan maksimum merupakan ekuivalen dari desain perpindahan tingkat MDOF, sehingga dapat dihitung dengan persamaan:

$$
\Delta_{d}=\frac{\sum_{i=1}^{n}\left(m_{i} \Delta_{i}^{2}\right)}{\sum_{i=1}^{n}\left(m_{i} \Delta_{i}\right)}
$$

3. Massa efektif untuk sistem SDOF pada sistem rangka dihitung dengan menggunakan persamaan:

$$
m_{e}=\frac{\sum_{i=1}^{n}\left(m_{i} \Delta_{i}\right)}{\Delta_{d}}
$$

4. Tinggi efektif yang setara dengan sistem SDOF dihitung dengan persamaan:

$$
H_{e}=\frac{\sum_{i=1}^{n}\left(m_{i} \Delta_{i} h_{i}\right)}{\sum_{i=1}^{n}\left(m_{i} \Delta_{i}\right)}
$$

Perilaku Struktur Gedung Bertingkat Ketidakberaturan Vertikal Kekakuan Tingkat 
5. Daktilitas perpindahan untuk sistem SDOF dapat dihitung dengan persamaan:

$$
\mu=\frac{\Delta_{d}}{\Delta_{y}}
$$

Perpindahan leleh untuk sistem rangka ditentukan dengan karakteristik simpangan leleh (yield drift) pada rangka dan dapat dihitung dengan Persamaan

$$
\Delta_{y}=\delta_{y} H_{e}
$$

Simpangan leleh pada rangka untuk tingkat ke-i dipengaruhi dengan karakteristik geometri bangunan dan kekuatan elemen itu sendiri. Kekuatan elemen dipengaruhi oleh nilai regangan material, panjang balok, juga tinggi efektif balok.

$$
\delta_{y}=0.5 \varepsilon_{y} \frac{L_{b}}{h_{b}} \text { Rangka Beton }
$$

6. Nilai redaman viscous ekuivalen untuk sistem SDOF untuk frame beton bertulang dihitung dengan persamaan:

$$
\xi_{F}=0.05+0.565\left(\frac{\mu_{F}-1}{\mu_{F \pi}}\right)
$$

7. Nilai periode efektif sistem berderajat kebebasan tunggal (SDOF) pada saat respon perpindahan puncak dengan redaman inelastis dari sistem dihitung dengan mengkonversi respon spektrum desain ke grafik spektra perpindahan $\left(S_{d}\right)$ dengan mengkonversi ke tingkat redaman viscous ekuivalen $\left(\xi_{\text {eq }}\right)$ lalu pada grafik spektra perpindahan ditarik nilai perpindahan rencana $\left(\Delta_{d}\right)$ sehingga nilai periode efektif sistem dapat diketahui.

$$
\begin{aligned}
& R_{\xi}=\left(\frac{0.07}{0.02+\xi}\right)^{0.5} \\
& T_{e}=\frac{\Delta_{d}}{\Delta_{\xi}} T_{d}
\end{aligned}
$$

8. Nilai kekakuan efektif bergantung pada nilai massa efektif dan periode efektif akan dihitung dengan persamaan:

$$
K_{e}=\frac{4 . \pi^{2} \cdot m_{e}}{T_{e}^{2}}
$$

9. Setelah nilai kekakuan efektif dihitung, maka nilai desain gaya geser dasar dapat dihitung menggunakan persamaan:

$$
V_{b a s e}=K_{e} x \Delta_{d}
$$

Prosedur desain DDBD untuk sistem ganda:

1. Langkah pertama adalah menentukan proporsi gaya geser dasar yang akan diterima oleh rangka dan dinding geser dengan persamaan:

$$
\begin{aligned}
& V_{F}=\beta_{F} V_{\text {base }} \\
& V_{W}=\left(1-\beta_{F}\right) V_{\text {base }}
\end{aligned}
$$

2. Menentukan tinggi wall contraflexure

$$
\begin{aligned}
& F_{i}=\frac{m_{i} H_{i}}{\sum m_{i} H_{i}} \\
& M_{\text {○TM }} \cdot i=V_{i} \times H_{n}
\end{aligned}
$$

3. Menentukan profil perpindahan leleh dinding geser dapat digunakan persamaan:

$$
\begin{aligned}
\text { Untuk } H_{i} & \leq H_{C F}, \\
\Delta_{y i} & =\phi_{y W}\left(\frac{H i^{2}}{2}-\frac{H i^{\mathrm{a}}}{6 H_{C F}}\right) \\
\text { Untuk } H_{i} & >H_{C F}, \\
\Delta_{y i} & =\phi_{y W}\left(\frac{H_{C F} H_{i}}{2}-\frac{H_{C F^{2}}}{6}\right)
\end{aligned}
$$


4. Desain profil perpindahan rencana dapat dihitung dengan persamaan:

Jika $\delta_{C F} \leq \delta_{C}$ maka,

$$
\Delta_{i}=\Delta_{y i}+\left(\phi_{l s}-\phi_{y W}\right) L_{p} H_{i}
$$

Jika $\delta_{C F}>\delta_{C}$ maka,

$$
\Delta_{D i}=\Delta_{y i}+\left(\delta_{c}-\phi_{y W} H_{C F} / 2\right) H_{i}
$$

Nilai simpangan pada tinggi contraflexure $\left(\delta_{C F}\right)$ harus dicek dengan nilai simpangan (drift) rencana, $\delta_{\tilde{C}}$, pada Persamaan (21) harus dikoreksi dengan dikalikan faktor koreksi $\omega_{\theta}$ sesuai persamaan (22)

$$
\omega_{\theta}=\left(1-\frac{(n-5)}{100}\right)\left(\frac{M_{\text {OTM.F }}}{M_{\text {OTM }}}+0.25\right)
$$

5. Desain perpindahan SDOF

Desain perpindahan tingkat MDOF harus dikonversi ke sistem SDOF di mana perpindahan maksimum merupakan ekuivalen dari desain perpindahan tingkat MDOF dengan persamaan:

$$
\Delta_{d}=\frac{\sum_{i=1}^{n}\left(m_{i} \Delta_{i}^{2}\right)}{\sum_{i=1}^{n}\left(m_{i} \Delta_{i}\right)}
$$

6. Tinggi efektif struktur yang setara dengan sistem SDOF dapat dihitung dengan persamaan:

$$
H_{e}=\frac{\sum_{i=1}^{n}\left(m_{i} \Delta_{i} h_{i}\right)}{\sum_{i=1}^{n}\left(m_{i} \Delta_{i}\right)}
$$

7. Massa efektif untuk sistem SDOF untuk sistem ganda dapat dihitung dengan persamaan:

$$
m_{e}=\frac{\sum_{i=1}^{n}\left(m_{i} \Delta_{i}\right)}{\Delta_{d}}
$$

8. Redaman viscous ekuivalen (equivalent viscous damping)

$$
\begin{aligned}
& \mu_{w}=\Delta_{d} / \Delta_{y w} \\
& \xi_{w}=0.05+0.444\left(\frac{\mu_{w}-1}{\mu_{w \pi}}\right)
\end{aligned}
$$

9. Distribusi gaya geser dasar DDBD

$$
F_{i}=F_{t}+0.9 V_{\text {base }}\left(m_{i} \Delta_{i}\right) / \sum_{i=1}^{n} m_{i} \Delta_{i}
$$

Adapun hasil perhitungan yang dilakukan dengan menggunakan metode DDBD didapatkan parameter nilai-nilai sebagai berikut:

Tabel 2 Parameter nilai metode DDBD sistem ganda arah $\mathrm{x}-\mathrm{x}$

\begin{tabular}{cccccc}
\hline No & Parameter & Struktur A0 & Struktur B1 & Struktur B2 & Struktur B3 \\
\hline 1 & $H c f$ & $46.05 \mathrm{~m}$ & $48.61 \mathrm{~m}$ & $54.50 \mathrm{~m}$ & $45.5 \mathrm{~m}$ \\
\hline 2 & $\omega_{\theta}$ & 0.711 & 0.724 & 0.701 & 0.728 \\
\hline 3 & $\Delta_{d}$ & $0.805 \mathrm{~m}$ & $0.907 \mathrm{~m}$ & $0.864 \mathrm{~m}$ & $0.886 \mathrm{~m}$ \\
\hline 4 & $m_{e}$ & $28239.81 \mathrm{ton}$ & $30408.97 \mathrm{ton}$ & $27786.26 \mathrm{ton}$ & $27963.77 \mathrm{ton}$ \\
\hline 5 & $H_{\theta}$ & $64.090 \mathrm{~m}$ & $70.753 \mathrm{~m}$ & $72.152 \mathrm{~m}$ & $67.873 \mathrm{~m}$ \\
\hline 6 & $\Delta_{y}$ & $0.421 \mathrm{~m}$ & $0.479 \mathrm{~m}$ & $0.512 \mathrm{~m}$ & $0.442 \mathrm{~m}$ \\
\hline 7 & $\mu$ & 1.912 & 1.894 & 1.688 & 2.005 \\
\hline 8 & $\xi_{\text {eq }}$ & 0.119 & 0.119 & 0.110 & 0.122 \\
\hline 9 & $R_{\xi}$ & 0.710 & 0.710 & 0.734 & 0.702 \\
\hline 10 & $T_{\theta}$ & 8.82 detik & $9.94 \mathrm{detik}$ & $9.16 \mathrm{detik}$ & $9.81 \mathrm{detik}$ \\
\hline 11 & $k_{e}$ & $14331.26 \mathrm{kN} / \mathrm{m}$ & $12150.35 \mathrm{kN} / \mathrm{m}$ & $13073.71 \mathrm{kN} / \mathrm{m}$ & $11471.43 \mathrm{kN} / \mathrm{m}$ \\
\hline 12 & $V_{\text {base }}$ & $11536.66 \mathrm{kN}$ & $11020.37 \mathrm{kN}$ & $11295.69 \mathrm{kN}$ & $10163.69 \mathrm{kN}$ \\
\hline
\end{tabular}


Tabel 3 Parameter nilai metode DDBD sistem rangka arah y - y

\begin{tabular}{cccccc}
\hline No & Parameter & Struktur A0 & Struktur B1 & Struktur B2 & Struktur B3 \\
\hline 1 & $\Delta_{d}$ & $0.822 \mathrm{~m}$ & $0.878 \mathrm{~m}$ & $0.879 \mathrm{~m}$ & $0.839 \mathrm{~m}$ \\
\hline 2 & $m_{e}$ & $31764,99 \mathrm{ton}$ & $33801,38 \mathrm{ton}$ & $31916,98 \mathrm{ton}$ & $31594,52 \mathrm{ton}$ \\
\hline 3 & $H_{\theta}$ & $60.398 \mathrm{~m}$ & $67.071 \mathrm{~m}$ & $67.350 \mathrm{~m}$ & $63.819 \mathrm{~m}$ \\
\hline 4 & $\Delta_{g}$ & $0.538 \mathrm{~m}$ & $0.599 \mathrm{~m}$ & $0.599 \mathrm{~m}$ & $0.568 \mathrm{~m}$ \\
\hline 5 & $\mu$ & 1.528 & 1.466 & 1.467 & 1.477 \\
\hline 6 & $\xi_{e q}$ & 0.112 & 0.107 & 0.107 & 0.108 \\
\hline 7 & $R_{\varepsilon}$ & 0.728 & 0.742 & 0.742 & 0.740 \\
\hline 8 & $T_{e}$ & 8.78 detik & 9.20 detik & 9.21 detik & 8.82 detik \\
\hline 9 & $k_{e}$ & $16267.45 \mathrm{kN} / \mathrm{m}$ & $15765.89 \mathrm{kN} / \mathrm{m}$ & $14854.65 \mathrm{kN} / \mathrm{m}$ & $16033.72 \mathrm{kN} / \mathrm{m}$ \\
\hline 10 & $V_{\text {base }}$ & $13371.84 \mathrm{kN}$ & $13842.45 \mathrm{kN}$ & $13057.24 \mathrm{kN}$ & $13452.29 \mathrm{kN}$ \\
\hline
\end{tabular}

\section{Hasil dan Pembahasan}

Hasil analisis struktur bangunan Gedung dengan menggunakan metode DDBD dengan target kinerja Life Safety yaitu 0,02 (batas drift) diperoleh parameter nilai-nilai sebagai berikut:

\subsection{Kurva kapasitas struktur}

Kurva kapasitas hasil dari analisis statik beban dorong menunjukkan hubungan antara gaya geser dasar (base shear) dan perpindahan atap akibat beban lateral yang diberikan pada struktur dengan pola pembebanan tertentu sampai pada kondisi ultimit atau target peralihan yang diharapkan.

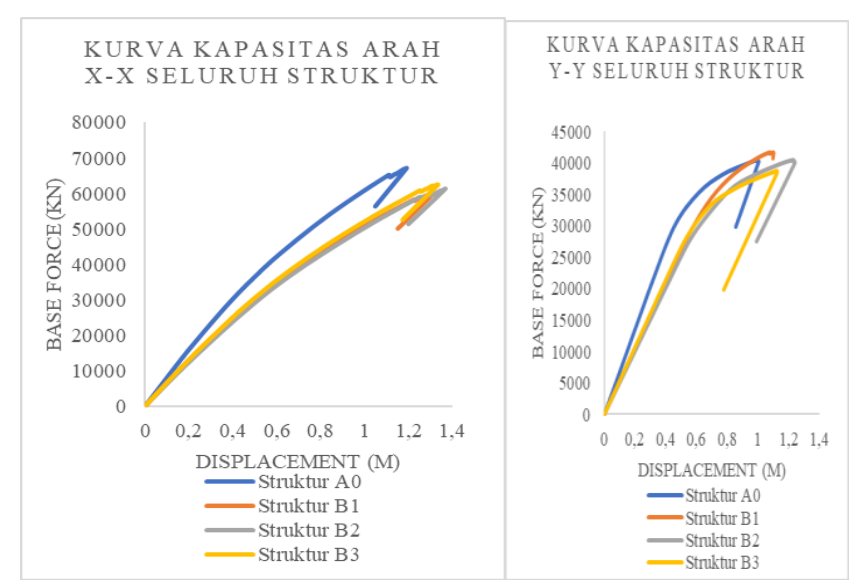

Gambar 4 Kurva kapasitas struktur A0, B1, B2, dan B3 arah x dan y

Hasil dari kurva kapasitas ialah nilai duktilitas yang mana nilai duktilitas adalah rasio antar simpangan maksimum struktur gedung pada saat mencapai kondisi di ambang keruntuhan dan simpangan struktur gedung pada saat terjadinya pelelehan pertama didalam struktur Gedung.

Tabel 4 Rekapitulasi nilai duktilitas arah $\mathrm{x}$ - x pada keseluruhan tipe struktur

\begin{tabular}{lcccc}
\hline \multicolumn{1}{c}{ Uraian } & Struktur A0 & Struktur B1 & Struktur B2 & Struktur B3 \\
\hline Displacement leleh $\left(\delta_{y}\right)$ & 0,143 & 0,141 & 0,141 & 0,1416 \\
\hline Displacement maksimum $\left(\delta_{w}\right)$ & 1,193 & 1,306 & 1,3681 & 1,3322 \\
\hline Nilai Duktilitas $\left(\mu_{\S}\right)$ & 8,34 & 9,26 & 9,70 & 9,41 \\
\hline \multicolumn{5}{l}{$\begin{array}{l}\text { Perilaku Struktur Gedung Bertingkat } \\
\text { Lunak Dengan Analisis Berbasis Kinerja - Arbain Tata }\end{array}$} \\
\end{tabular}


Dari Tabel 4 dan Tabel 5, diketahui bahwa struktur bangunan Gedung A0, B1, B2 dan B3 pada arah $\mathrm{x}$ dan y dikategorikan dengan daktalitas penuh (full ductility) dengan nilai daktilitas lebih dari 3,00.

Tabel 5 Rekapitulasi nilai duktilitas arah y - y pada keseluruhan tipe struktur

\begin{tabular}{lcccc}
\hline \multicolumn{1}{c}{ Uraian } & Struktur A0 & Struktur B1 & Struktur B2 & Struktur B3 \\
\hline Displacement leleh $\left(\delta_{y}\right)$ & 0,15 & 0,15 & 0,15 & 0,1500 \\
\hline Displacement maksimum $\left(\delta_{u}\right)$ & 1,087 & 1,1025 & 1,2421 & 1,1271 \\
\hline Nilai Duktilitas $\left(\mu_{s}\right)$ & 6,72 & 7,35 & 8,28 & 7,51 \\
\hline
\end{tabular}

\subsection{Evaluasi kinerja}

Nilai kinerja struktur hasil desain akan dibandingkan dengan nilai kinerja struktur yang didesain diawal saat perhitungan dengan metode Direct Displacement Based Design (DDBD). Metode Spektrum Kapasitas atau Capacity Spectrum (ATC-40) secara default sudah built-in terdapat pada program ETABS v9.7.4. Untuk mendapatkan performance point maka yang dibutuhkan terlebih dahulu yaitu harus memasukkan beberapa parameter yang dihitung sesuai dengan dokumen ATC-40. Adapun parameter yang dihitung yaitu:

$$
\begin{aligned}
& C_{A}=0,4 \times S_{M S}=0,4 \times 1,164=0,466 \\
& C_{V}=S_{M 1}=0,776
\end{aligned}
$$

Sedangkan untuk Structural Behavior Type sesuai dengan Tabel 9-3 ATC40 digunakan tipe $\mathrm{B}$, yang artinya struktur merupakan bangunan baru dan mempunyai long period response.

\begin{tabular}{|c|c|c|c|c|c|}
\hline \multirow[t]{2}{*}{ Arah } & \multirow[t]{2}{*}{ Parameter } & \multicolumn{4}{|c|}{ Struktur } \\
\hline & & Struktur A0 & Struktur B1 & Struktur B2 & Struktur B3 \\
\hline \multirow[t]{6}{*}{$\begin{array}{l}\text { Arah } \\
\mathbf{x}-\mathbf{x}\end{array}$} & $\begin{array}{l}\text { Target Perpindahan } \\
\text { Rencana } D D B D(m)\end{array}$ & 0,805 & 0,907 & 0,864 & 0,886 \\
\hline & $\begin{array}{l}\text { Performance Point } \\
\text { Displacement } A T C-40\end{array}$ & 0,747 & 0,863 & 0,839 & 0,830 \\
\hline & Tinggi Struktur (m) & 96 & 105 & 105 & 105 \\
\hline & Drift aktual & 0,0078 & 0,0082 & 0,0080 & 0,0079 \\
\hline & Level Kinerja & $\begin{array}{c}\text { Immediate } \\
\text { Occupancy } \\
\text { (IO) }\end{array}$ & $\begin{array}{c}\text { Immediate } \\
\text { Occupancy } \\
(I O)\end{array}$ & $\begin{array}{c}\text { Immediate } \\
\text { Occupancy } \\
(I O)\end{array}$ & $\begin{array}{c}\text { Immediate } \\
\text { Occupancy } \\
\text { (IO) }\end{array}$ \\
\hline & Nilai Duktilitas & 8,34 & 9,26 & 9,70 & 9,41 \\
\hline \multirow[t]{6}{*}{$\begin{array}{l}\text { Arah } \\
y-y\end{array}$} & $\begin{array}{l}\text { Target Perpindahan } \\
\text { Rencana } D D B D(m)\end{array}$ & 0,822 & 0,878 & 0,879 & 0,839 \\
\hline & $\begin{array}{l}\text { Performance Point } \\
\text { Displacement } A T C-40\end{array}$ & 0,700 & 0,861 & 0,818 & 0,796 \\
\hline & Tinggi Struktur $(\mathrm{m})$ & 96 & 105 & 105 & 105 \\
\hline & Drift aktual & 0,0073 & 0,0082 & 0,0078 & 0,0076 \\
\hline & Level Kinerja & $\begin{array}{c}\text { Immediate } \\
\text { Occupancy } \\
\text { (IO) }\end{array}$ & $\begin{array}{c}\text { Immediate } \\
\text { Occupancy } \\
\text { (IO) }\end{array}$ & $\begin{array}{c}\text { Immediate } \\
\text { Occupancy } \\
(I O)\end{array}$ & $\begin{array}{c}\text { Immediate } \\
\text { Occupancy } \\
\text { (IO) }\end{array}$ \\
\hline & Nilai Duktilitas & 6,72 & 7,35 & 8,28 & 7,51 \\
\hline
\end{tabular}

Tabel 6 Rekapitulasi perilaku struktur desain berbasis kinerja 
Pada Tabel 6 dapat dilihat bahwa untuk masing masing arah pada Metode Spektrum Kapasitas ATC-40 menghasilkan nilai target perpindahan yang hampir mendekati dengan nilai rencana DDBD. Secara keseluruhan struktur berada pada level kinerja Immediate Occupancy (IO). Dengan level kinerja desain Life Safety maka struktur belum mencapai target kinerja desain, tetapi mendekati nilai kinerja desain dengan level kinerja tercapai lebih tinggi dibanding rencana.

\subsection{Perbandingan Drift dan Displacement}

Nilai drift dan displacement aktual hasil analisa pushover digunakan untuk mengetahui perilaku struktur dengan ketidakberaturan vertikal yang didesain menggunakan analisis berbasis kinerja Direct Displacement Based Design (DDBD), maka sesuai Priestley et.al 2007, nilai drift desain dan hasil analisis nonlinier pushover juga displacement profil desain dan hasil pushover perlu dibandingkan.

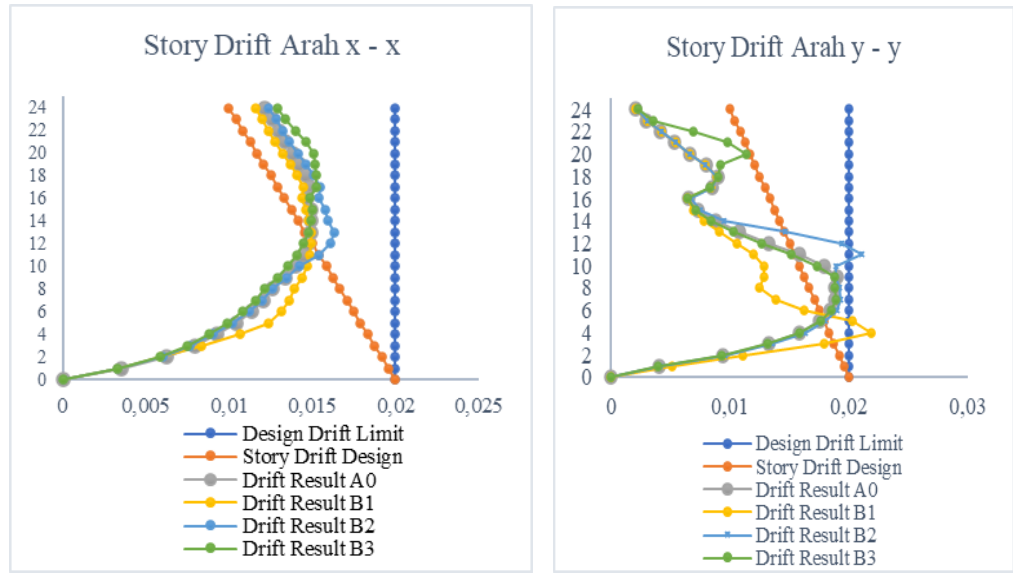

Gambar 5 Grafik perbandingan drift struktur A0, B1, B2, dan B3 arah x dan y

Gambar 5 Grafik Story Drift arah x-x memperlihatkan bahwa grafik drift result hasil dari analisis pushover untuk keseluruhan tipe struktur nilainya masih jauh dari grafik design drift limit, namun pada pertengahan tingkat dimulai dari lantai ke 12-24 nilai dari grafik drift result untuk keseluruhan tipe struktur melebihi nilai dari story drift design namun tidak melebihi nilai design drift limit yang berarti bahwa untuk masing-masing lantai masih berada dalam level kinerja Life Safety sesuai desain.

Pada Grafik Story Drift arah y-y memperlihatkan bahwa grafik drift result hasil dari analisis pushover untuk struktur A0 pada lantai 5-10 melewati batas dari grafik story drift design namun masih berada dalam batas kinerja Life Safety karena belum melewati garis Drift Limit. Struktur B1 dan B2 terlihat bahwa drift result hasil analisis pushover melewati grafik design drift limit karena pengaruh ketidakberaturan vertikal tingkat lunak di mana kekakuan lateralnya kurang dari $70 \%$ tingkat diatasnya, di mana tinggi kolom antar lantai yang berbeda cukup signifikan antara lantai yang ditinjau dengan lantai di bawahnya. Namun berbeda dengan Struktur B3 di mana terdapat ketidakberaturan vertikal pada lantai bagian atas hasil dari nilai drift analisis pushover masih dalam batas design drift limit.

Gambar 6 Grafik Displacement arah x-x, dapat diketahui bahwa nilai displacement untuk arah $\mathrm{x}-\mathrm{x}$ pada Struktur B3 hasil analisis pushover nilainya yang paling mendekati serta lebih kecil dibandingkan dengan nilai displacement 
rencana DDBD Struktur A0. Nilai dari Struktur B1 dibandingkan terhadap struktur B2 dan B3 memiliki nilai displacement terbesar serta lebih besar dibandingkan dengan nilai displacement rencana DDBD Struktur A0 pada lantai 1-20, namun pada lantai 21-24 diketahui bahwa nilai displacement Struktur B1 sudah lebih kecil dibandingkan struktur A0. Nilai dari Struktur B2 memiliki nilai yang lebih besar dibandingkan nilai displacement rencana DDBD Struktur A0 pada lantai 1-18, namun lebih kecil dibanding struktur B1, akan tetapi diketahui pula bahwa nilai displacement yang terjadi pada Struktur B2 pada bagian atas bangunan yakni lantai 24 memiliki nilai paling kecil dibanding keseluruhan tipe struktur terhadap struktur A0. Terlihat struktur bangunan yang mempunyai ketidak beraturan kekakuan tingkat lunak tipe B1 akan menghasilkan gaya geser yang menyimpang dari struktur bangunan dasar (A0) baik pada analisis Static Push-over maupun non linier time history analysis. Hai ini diakibatkan oleh sifat diskontinu didinding geser pada lantai yang lemah tersebut menyebakan adanya anomaly nilai geser sehingga memberi distraksi terhadap gaya geser lantai lainnya ada kemiripan dengan perilaku dari hasil analisis (Budiono, 2016).
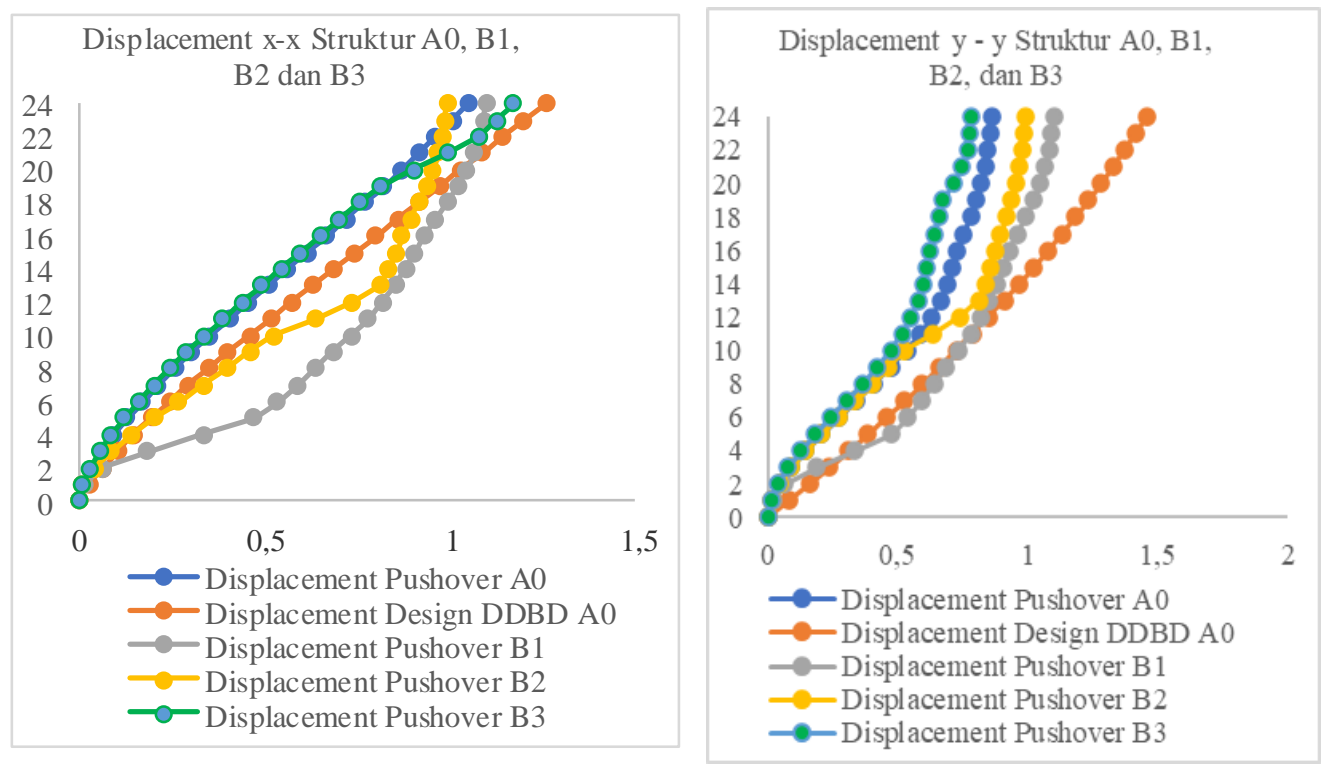

Gambar 6 Grafik perbandingan displacement dtruktur A0, B1, B2, dan B3

Grafik Displacement arah y-y, diketahui bahwa nilai displacement untuk arah y - y pada Struktur B1 hasil analisis pushover pada bagian lantai 4-10 lebih besar dibandingkan nilai displacement rencana DDBD Struktur A0, namun pada lantai 11-24 diketahui bahwa nilai Struktur B1 lebih kecil dibanding nilai Struktur A0, lihat Gambar 5. Dari gambar tersebut juga diketahui bahwa, untuk Struktur B2 dan B3, nilai aktual displacement yang terjadi lebih kecil dibanding struktur A0 dan nilai struktur B3 dibandingkan dengan keseluruhan tipe struktur memiliki nilai displacement yang paling kecil pada lantai teratas struktur bangunan.

\section{Kesimpulan}

Perilaku struktur gedung bertingkat ketidak beraturan vertikal kekakuan tingkat lunak dengan analisis berbasis kinerja menunjukkan bahwa lantai satu memberikan respon yang paling berpengaruh pada bagian struktur sehingga 
bagunan B1 paling menyimpang jika dibandingkan dengan bangunan dasar A0, memiliki nilai safety paling rendah jika dibandingkan dengan ketidak beraturan kekakuan tingkat lunak pada lantai di atas serta memiliki tingkat akurasi yang paling buruk jika dilakukan perbandingan antara metode push-over terhadap non linier time history analysis pada B2 dan B3.

Hasil perbandingan nilai drift pada arah $\mathrm{y}-\mathrm{y}$ (sitem rangka) menunjukkan hasil bahwa untuk struktur A0 pada lantai 5-10 melewati batas dari grafik story drift design namun masih berada dalam batas kinerja Life Safety karena belum melewati garis Drift Limit. Pada Struktur B1 dan B2 terlihat bahwa drift result hasil analisis pushover melewati grafik design drift limit karena pengaruh ketidakberaturan vertikal tingkat lunak di mana kekakuan lateralnya kurang dari $70 \%$ tingkat di atasnya di mana tinggi kolom antar lantai yang berbeda cukup signifikan antara lantai yang ditinjau dengan lantai di bawahnya, namun berbeda dengan Struktur B3 di mana terdapat ketidakberaturan vertikal pada lantai bagian atas hasil dari nilai drift analisis pushover masih dalam batas design drift limit.

Hasil perbandingan nilai displacement pada arah $\mathrm{x}-\mathrm{x}$ (sistem ganda) dan arah $\mathrm{y}-\mathrm{y}$ (sistem rangka) untuk semua tipe struktur menunjukkan bahwa, displacement hasil analisis pushover nilainya lebih kecil dibanding dengan rencana DDBD untuk tiap tipe struktur yang didesain.

\section{Daftar Kepustakaan}

A, T., Imran and Imron, F, 2018. Evaluasi Kinerja Struktur Beton Gedung Fakultas Ekonomi Unkhair Dengan Analisis Pushover Atc-40. Jurnal Sipil Sains, 8(15), pp. 1-10.

ACI-318, 2014. Building Code Requirements for Structural Concrete (ACI 318S14) and Commentary (ACI 318SR-14). American Concrete Institute.

Budiono, B, 2016. Perilaku Struktur Bangunan dengan Ketidakberaturan Vertikal Tingkat Lunak Berlebihan dan Massa Terhadap Beban Gempa. Jurnal Teknik Sipil ITB, 23(2), pp. 113-126, doi: 10.5614/jts.2016.23.2.4.

Cimellaro, G. P., Giovine, T. and Lopez-Garcia, D, 2014. Bidirectional Pushover Analysis of Irregular Structures. Journal of Structural Engineering, 140(9), p. 04014059, doi: 10.1061/(asce)st.1943-541x.0001032.

Fajfar, P, 2018. Analysis in seismic provisions for buildings: past, present and future: The fifth Prof. Nicholas Ambraseys lecture. Bulletin of Earthquake Engineering, Springer Netherlands, doi: 10.1007/s10518-017-0290-8.

Filiatrault, A. and Sullivan, T, 2014. Performance-based seismic design of nonstructural building components: The next frontier of earthquake engineering. Earthquake Engineering and Engineering Vibration, 13(1), pp. 17-46, doi: 10.1007/s11803-014-0238-9.

Hakim, R. A., Alama, M. S. and Ashour, S. A, 2014. Seismic Assessment of RC Building According to ATC 40, FEMA 356 and FEMA 440. Arabian Journal for Science and Engineering. 39(11), pp. 7691-7699, doi: 10.1007/s 13369-014-1395-x.

Hamidia, M., Filiatrault, A. and Aref, A, 2015. Seismic Collapse Capacity-Based Evaluation and Design of Frame Buildings with Viscous Dampers Using Pushover Analysis. Journal of Structural Engineering, 141(6), p. 04014153 , doi: 10.1061/(asce)st.1943-541x.0001114. 
Kalkan, E. and Kunnath, S. K, 2006. Adaptive Modal Combination Procedure for Nonlinear Static Analysis of Building Structures. Journal of Structural Engineering, 132(11), pp. 1721-1731, doi: 10.1061/(asce)07339445(2006)132:11(1721).

Lilik Hendri Suryo Anom, Wibowo Wibowo, S. S, 2013. Analisis Kinerja Struktur Dengan Metode Performance Based Design Terhadap Gedung Ketidakberaturan Vertikal. Jurnal Online Matriks Teknik Sipil, 1(3), pp. 227-234, Available at: http://matriks.sipil.ft.uns.ac.id/index.php/MaTekSi/ article/view/74.

Mirjalili, M. R. and Rofooei, F. R, 2020. Dynamic-Based Pushover Analysis for Two-Way Plan-Asymmetric Buildings under Bidirectional Seismic Excitation. Journal of Structural Engineering, 146(3), p. 04019223, doi: 10.1061/(asce)st.1943-541x.0002501.

Narayan, S. et al, 2018. Collapse of Damaged Steel Building Frames because of Earthquakes. Journal of Performance of Constructed Facilities, 32(1), p. 04017128, doi: 10.1061/(asce)cf.1943-5509.0001125.

Pangemanan, S. and Mantiri, H. G, 2017. Analisis Pushover Perilaku Seismik Struktur Bangunan Bertingkat: Studi Kasus Bangunan Ruko. Prosiding Simposium II, 40(September), pp. 978-979.

Resti Oktaviani, S. S, 2016. Pengaruh Keberadaan Kawasan Kota Baru Lippo Karawaci Terhadap Perkembangan Fisik, Ekonomi, dan Sosial Pada Kawasan di Sekitarnya. Ruang: Jurnal Perencanaan Wilayah dan Kota, 2(1), pp. 1-10, doi: 10.14710/ruang.2.1.1-10.

Saedi-Daryan, A., Soleimani, S. and Hasanzadeh, M, 2018. Extension of the Modal Pushover Analysis to Assess Structures Exposed to Blast Load. Journal of Engineering Mechanics, 144(3), p. 04018006, doi: 10.1061/(asce)em.1943-7889.0001417.

Saleemuddin, M. Z. M. and Sangle, K. K, 2017. Seismic damage assessment of reinforced concrete structure using non-linear static analyses. KSCE Journal of Civil Engineering,21(4), pp.1319-1330,doi: 10.1007/s12205-016-0541-2.

Sulthan, F, 2017. Analisis Struktur Gedung Bertingkat Menggunakan Kombinasi Sistem Struktur Frame Tube Dan Waffle Slab. Prosiding Simposium II UNIID, (September), pp. 978-979. Available at: https://www.researchgate.net/publication/334248289.

Tafakori, E., Pourzeynali, S. and Estekanchi, H. E, 2017. Probabilistic seismic loss estimation via endurance time method. Earthquake Engineering and Engineering Vibration,16(1),pp. 233-245, doi: 10.1007/s11803-017-0379-8.

Vafaei, M. and Alih, S. C, 2018. Seismic vulnerability of air traffic control towers. Natural Hazards. Springer Netherlands, 90(2), pp. 803-822, doi: 10.1007/s11069-017-3072-3.

Zeng, X. et al, 2016. Application of the FEMA-P58 methodology for regional earthquake loss prediction. Natural Hazards. Springer Netherlands, 83(1), pp. 177-192, doi: 10.1007/s11069-016-2307-z. 